The

\section{Westhallstattkreis as spaces of contact}

\author{
Philipp W. Stockhammer[*;**] \\ Bogdan Athanassov[***]
}

[*]Ludwig Maximilians University (LMU) Munique (Baviera) - Germany.

E-mail: philipp.stockhammer@lmu.de

$\left[{ }^{* *}\right]$ Max Planck Institute for the Science of Human History - Jena (Thuringia) - Germany

ORCID: https://orcid.org/0000-0003-4702-9372

[***]New Bulgarian University - Sofia - Bulgaria. E-mail:bo.atana@nbu.bg

ORCID: https://orcid.org/0000-0002-3971-7151

\begin{abstract}
The idea of the contact zone has already been of interest for archaeologists for a long time, but rarely had they been applied to the study of the so-called Westhallstattkreis. Both the 'contact zone' as well as the Westhallstattkreis have generally been understood as geographically definable spaces: the first one as a space where cultural encounter unfolded its transformative potential; the second one as a space where particular types of objects and features were found. Based on the understanding of spaces of encounter by Marie Louise Pratt and Richard White, the 'contact zone' will be redefined for the study of the Westhallstattkreis. We suggest dissolving the 'contact zones' from geographically defined spaces and seeing them - as well as the Westhallstattkreis - as performative spaces.
\end{abstract}

Keywords: Westhallstattkreis; Contact space; Appropriation.

\section{A zona hallstattiana ocidental como zona de contato}

Resumo: A ideia de uma zona de contato tem sido de interesse para arqueólogos por um longo tempo, mas tem sido raramente empregada para o estudo da chamada "zona hallstattiana ocidental". Tanto a "zona de contato" quanto a "zona hallstattiana ocidental" têm geralmente sido compreendidas como espaços geograficamente definidos: a primeira como um espaço onde contatos culturais revelam seu potencial transformador; a segunda como um espaço onde tipos particulares de objetos e características são encontrados. Com base no entendimento de espaços de encontro de Marie Louise Pratt e Richard White, redefinimos a "zona de contato" para o estudo da "zona hallstattiana ocidental". Sugerimos que temos de romper com as "zonas de contato" como espaços geograficamente definíveis e que devemos, ao contrário, compreender "zonas de contato", bem como a "zona hallstattiana ocidental", enquanto espaços performativos.

Palavras-chave: Zona hallstattiana ocidental; Espaço de contato; Apropriação. 


\section{The Westhallstattkreis and its southern contact}

Being in contact is crucial — in the past as in the present — and there is no doubt that people were aiming at contact with others throughout all times and spaces. This article picks up the notion of the 'contact zone' which has enjoyed much popularity in the humanities for the past two decades. ' 'Contact zone' has also sporadically found its use in the study of the Early Iron Age in Central Europe (Brun, 1988, p. 128-143; Dietler, 2010, p. 13.), but it is still far from being used as a heuristic category, and its potential has not been evaluated for the study of this region and time.

For many decades, the study of cultural encounter between Early Iron Age Central Europe (ca. 700-400 BC) and the Mediterranean has been dominated by the bipolar opposition of 'Greeks' vs. 'Celts'. Both were understood as radically different entities epitomizing very different kinds of societal organisation, world views, life styles, daily practices etc. The differences between both entities were emphasized. Homogeneity within each entity was assumed, generally not further problematized (in the case of the 'Greeks') or even stressed (in the case of the 'Celts') while the spectacular finds from a very few places were considered sufficient enough to explain the situation at all other sites (Eggert, 1989, p. 53). The different forms of contact between the two entities have been intensively discussed and a broad range of complementing (or sometimes also contradictive) explanations have been brought forward - from transhumant herders via foreign visitors who brought presents/keimelia up to intense economic exchange or the long-term stay of specialists from the Mediterranean in order to transfer technological knowledge - e.g. in the case of the construction of the mud brick wall of the Heuneburg. The focal area of this contact was generally equated with the so-called Westhallstattkreis.

Up to the present, the Westhallstattkreis is understood as a particular region, within which the evidence and/or ubiquity of characteristic finds and/or features allow us to define an 'archaeological culture' which is subsequently almost exclusively equated with the 'Early Celts'. The type-fossils taken as a basis for the regional delimitation differ from author to author. Nils Müller-Scheeßel devoted an extensive study to the different ways and kinds the Westhallstattkreis was defined by different authors (Müller-Scheeßel, 2000). At that moment, there seems to be some general agreement that southwestern Germany, northern Switzerland and parts of eastern France could be seen as its core, whereas its eastern boarder within southern Germany and western border in eastern France are still disputed. Processual

${ }^{1}$ This is not the place to cover the large body of literature in many different disciplines which has followed and discussed Pratt's influential writings (e.g. Clifford, 1997; Schorch, 2013; with further literature). Critical voices have pointed out that she represented the meeting cultures as too compact or put too much emphasis on texts and narratives. Christoph Ulf (2014, p. 469-504) chose 'contact zone' as an overarching term under which very different kinds of places and spaces were subsumed. 
approaches to the study of the Westhallstattkreis did not try to overcome the predominant notion of a particular and rather homogenous zone, but just updated the terminology by locating it as 'periphery' within the popular world-system-theory (Frankenstein and Rowlands, 1978, p. 109). In the past years, network approaches and quantitative spatial analyses became popular and were taken as a basis for spatial analyses and definitions (Nakoinz, 2009, p. 87-100, 2013, 2014, p. 187-199).

The aim of our contribution is not to overcome or replace these spatial approaches to the Westhallstattkreis, but rather ask, if the current approaches are sufficient for understanding the complexity of the intercultural encounter, appropriation and resistance, material and relational entanglements (cf. Stockhammer, 2012a, p. 43-58; Hofmann and Stockhammer, 2017, p. 45-66). The material remnants of intercultural encounter are most prominent in the material evidence from the Westhallstattkreis - from famous imported objects (e.g. Krater of Vix, Attic pottery, Mediterranean transport amphorae) to local products which were inspired by Mediterranean counterparts (e.g. beaked jugs, Heuneburg goblets) or architecture created under the supervision or with the knowledge of Mediterranean specialists (esp. the mud brick wall of the Heuneburg). The Westhallstattkreis as such is, of course, no relevant actor, but the people living in the referred time in this respective region are. However, it has generally been assumed that the different actors within this region had similar motivations in relation to their effort to acquire and appropriate Mediterranean objects, and - if possible - also life styles in the sense of social practices such as feasting. It is our aim to increase the awareness of the possibility of differences of interaction with objects, ideas and practices transferred from the Mediterranean through different actors and channels and of different motivations of local actors to acquire and appropriate them.

\section{Evaluating 'contact zone' and 'middle ground'}

The spatial correlate of intercultural encounter has found much attention in the humanities over the past decades - especially in and around the field of Postcolonial Studies. The two most prominent approaches were brought forward by Marie Louise Pratt, who defined the 'contact zone', and Richard White, who proposed the 'middle ground' as the space of cultural encounter. In our view, it is necessary to be aware of the potentials and pitfalls of these approaches, instead of using them in a metaphorical way without any further reflection. Therefore, we will start our thoughts on the link of intercultural encounter and space by a critical evaluation of both concepts.

Marie Louise Pratt (1991, p. 33-40) first published her concept in the Arts of the Contact Zone in 1991 and in the subsequent year 1992 in Imperial Eyes: Travel Writing and Transculturation (Pratt, 2008). She defined 'contact zones' as ‘social spaces where disparate cultures meet, 
clash, and grapple with each other, often in highly asymmetrical relations of domination and subordination - like colonialism, slavery, or their aftermaths' (Pratt, 2008, p. 7; almost identical: Pratt, 1991, p. 1). Consequently, her definition of 'contact zones' is based on two underlying concepts, i.e. 'social space' and the transformative power of colonial encounters.

With the noun 'contact' she aims to underline 'the interactive, improvisational dimensions of colonial encounters' (Pratt, 2008, p. 8) as the basis of 'transculturation'. Pratt's understanding of 'contact' is very much influenced by the notion of 'contact language' in linguistics where it refers to an improvised language that develops among speakers of different tongues who need to communicate with each other consistently, usually in the context of trade (Pratt, 2008, p. 8). In her view, contact zones are not only produced in situations of conquest and war, although the asymmetrical character of the encounters remains crucial to her. She also focuses on bilingualism, pidginization and dialogue, which create the basis of what she designates as 'transculturation', thereby following Ferdinando Ortiz's (1995) nomenclature. Pratt clearly states: 'Transculturation is a phenomenon of the contact zone' (Pratt, 2008, p. 7; almost identical: Pratt, 1991, p. 2). It is the key feature for its distinction. The textual sources evaluated by Pratt share the common feature that in all of them the action takes place on the margins of the influence of colonial powers. That is why Pratt claims that 'contact zone' in her discussion 'is often synonymous with 'colonial frontier'. But while the latter term is grounded within a European expansionist perspective (the frontier is a frontier only with respect to Europe), 'contact zone' shifts the center of gravity and the point of view' (Pratt, 2008, p. 8).

The noun 'zone' is defined as 'social space' (Pratt, 1991, p. 1, 2008, p. 7). However, there is hardly any other information about her understanding of 'space' than that 'contact zone' designates 'the space in which peoples geographically and historically separated come into contact with each other and establish ongoing relations' (Pratt, 2008, p. 8). For Pratt, 'social space' is not a permanent attribute of a particular geographical space. Frontier and contact zones are produced in the description and are created by factors ranging from the people, who have made contact, up to the audiences of their texts. The social nature of Pratt's contact zone is probably the reason why she concentrates on narratives and texts and not on physical or geographical characteristics of the contact zone. Pratt's frontiers are not linear boundaries separating people, but liminal mosaics where different people meet (Blake, 2004, p. 240). The concept is extremely dynamic, since every interaction of people creates a social space, i.e. a contact zone.

In the same year as Pratt's Imperial Eyes, Richard White's monograph The Middle Ground: Indians, Empires, and Republics in the Great Lake Region, 1650-1815 was published. White created his concept of the 'middle ground' in order to overcome simplified notions of acculturation in his analysis of the encounter of European settlers and local Indian populations in North America: 'The middle ground is the place in between: in between 
cultures, peoples, and in between empires and the non-state world of villages.' (White, 2011, p. x). Following White's argument, the 'middle ground grew according to the need of people to find a means, other than force, to gain the cooperation or consent of foreigners' (White, 2011, p. 52). Taking White literally, the middle ground was not produced, but it is the analytical denomination of a particular place, and the actors 'operated on the middle ground' or 'in the middle ground' (White, 201l, p. x). Contrary to some take-overs of the concept for archaeology (Malkin, 201l; Antonaccio, 2013), the middle ground should not be understood as a demilitarized zone. White (2011, p. xii) insists that it is also not simply about a compromise between two collaborating parties (a phenomenon widely recognised before him), but about the process of mediation. Therefore, one must not underrate the violent character of the middle ground and also not overemphasize the act of persuasion, as the notion of misunderstanding is crucial for White (2006, p. 10; 2011, p. xiii). An important prerequisite for the creation of a middle ground is a rough balance of power, or the inability on both sides to exert enough power to force the other side to change. As a consequence, the alliance rests on constant war-and-peace-making. Another crucial feature is the mutual need or desire for the possessions of the other side. Following White, the middle ground emerged as an alliance in the Upper Country of French Canada because 'whites could neither dictate to Indians, nor ignore them' (White 201l, p. xxvi; cf. Deloria 2006, p. 16). Thereby, a new system of meeting and exchange was created (White, 2011, p. xxvi). One of the reasons for the popularity of White's ideas is that he neither sees mediation in the Upper Country as a French invention and imposition, nor as an Indian diplomatic strategy of compromise in order to survive. For him, it was the emergence of a new hybrid world, where creative misunderstandings were capitalized (White, 201l, p. xxi). ${ }^{2}$ Another reason for the popularity of the 'middle ground' is that it has turned to a powerful trope providing 'one of the baste articulations of the practice of new cultural production in cross-social and cross-political contexts' (Deloria, 2006, p. 16) - similar to Pratt's contact zones. In White's case the actors of the imperial powers and the native villagers constitute equal partners during the encounters - neither falling in the limitations of world-systems perspectives nor ignoring the imperial agency. The mutual interest of e.g. trading powers and allies in their endeavour to get along with each other (linguistically, culturally, economically) generates previously unseen flows of information and knowledge.

Pratt and White are united in their interest to study the transformative power of intercultural encounter within a framework of strong asymmetries of power. Pratt opens her concept for all possible situations of contact and her contact zone emerges through human

2 The emphasis of misunderstandings as an important path of communication (White, 2006, p. 13; White, 2011, p. xiii, xx, xxi, xxiv) is reminiscent of Bruno Latour's (1986) - and subsequently - Joseph Maran's (2011, p. 283) notion of 'lost in translation', who stress that only the transformation of meaning through translation made foreign practices, objects and ideas accessible to the local context. 
practice in every situation and at every time. White, however, clearly limits his concept to colonial situations and an associated atmosphere of military conflicts and violence and, therefore, only a very specific and limited form of a contact zone. Both authors emphasize the importance of the performative practice of communication and the making of meaning as defining for the spaces they analyse.

How can archaeologists focussing on cultural encounter within Early Iron Age Central Europe benefit from the postcolonial insights and concepts of action within space and actions creating space? It immediately becomes clear that White's crucial precondition for a 'middle ground', i.e. a colonial situation, cannot be applied to Central Europe in the Early Iron Age - in contrast to e.g. Iron Age Gaul (cf. Dietler, 2010). ${ }^{3}$ In our view, the openness of Pratt's concept makes it much easier to be appropriated for or at least inspire archaeological studies which focus on the relation between intercultural encounter and space. Pratt's dynamic understanding of the contact zone emphasizes its momentary state and its shifting perception by past actors and/or present-day scholars. However, if archaeologists are interested in appropriating 'contact zone' as an analytical tool, it seems necessary to transform her model with regard to three different aspects:

First, it is more appropriate to speak of 'contact spaces' instead of 'contact zones'. Pratt's notion does not refer to a unified belt-like space, as the word 'zone' might suppose, but to a momentary social space where social interaction happens. ${ }^{4}$ This interaction leads to phenomena that Pratt terms 'transcultural'5 and which we would call 'entangled' (Stockhammer, 2012a-b). However, Pratt does not seem to be interested in the link between her fluid spaces and particular places. In her concept, this link remains open and place does not seem to be an important category.

Secondly, one has to emphasize that Pratt's 'disparate cultures', which meet and constitute the contact zone at this very moment (Pratt, 2008, p. 7), are nothing more than entities created during the scholarly analysis. Especially in (early) modern colonial situations, the definition of such disparate entities seems most natural, but we should not forget that even in these contexts the perception and definition of entities is nevertheless a heuristic step in the analysis and not the acknowledgement of existing entities. Although Pratt chose Ortiz' notion of 'transculturation', her understanding of intercultural admixture seems to

\footnotetext{
3 The concept of the 'middle ground' has rarely been introduced into historical or archaeological analyses. Most prominently is the work of Irad Malkin, who uses 'middle ground' in a less conceptual but rather broad metaphorical way for places which he chose as a focus of historical analysis (e.g. Malkin, 1998, 2001). Christoph Ulf (2014) understands the 'middle ground' as a particular category of a contact zone (not in the sense of Pratt, but rather the general communis opinio). In his view, the 'middle ground' might be a useful analytical concept if it is used in White's narrow definition and not in a rather metaphorical way.

${ }^{4}$ This is not the place to review the conceptualization of 'space', which has been a most vivid issue not only since the proclamation of the spatial turn (for an overview cf. Crang and Thrift, 2000; Günzel, 2010; Knappett, 2011; Hofmann, 2015).

${ }^{5}$ In the sense of Ortiz (1995)
} 
be rooted in the biological understanding of terms like hybridization and not related to our own understanding of 'transculturality' (Stockhammer and Forberg, 2017). ${ }^{6}$ Following Ortiz (1995), 'transculturation' denotes a process of transformation that unfolds through extended contacts and relationships between cultures. Transcultural Studies took this as a starting point, but have gone beyond this understanding by emphasizing that there are no 'pure' or discrete cultures, but that all social phenomena defined by us as cultures are the result of transcultural entanglements which again also have a long history and must not be linked with modernity only. We follow this transcultural approach in order to overcome a notion of culture defined as ethnically bounded and contained within a territorial frame, i.e. the traditional, container-like understanding of culture (Eibach, Opitz-Belakhal and Juneja 2012; Juneja and Falser, 2013; Flüchter and Schöttli, 2014; Stockhammer and Forberg, 2017). Cultures are invariably constituted by interaction, entanglement and reconfiguration. Cultures are, therefore, processes in continuous reconfiguration due to intercultural contact. Processes of identity formation and stabilisations of cultural norms are also important features of a contact space, as entanglement and persistency are in a dialectic relationship with each other. By no means should, the whole world be understood as a 'contact space', even if different people and groups constantly encounter almost everywhere. However, such a broad understanding would deprive the concept of its epistemological value. It has to be applied in a precise and careful manner in the context of the analysis of specific historical situations.

In consequence, we suggest to rephrase Pratt's (2008, p. 7) definition of the contact zone as follows: contact spaces are social spaces produced instantaneously where human actors meet, perceive and constitute otherness, clash, and grapple with each other. ${ }^{7}$

\section{Re-thinking 'contact zone' and the Westhallstattkreis}

We now have to transform this rather abstract definition into a heuristically useful methodological approach for archaeology. In our view, this deduction of a methodology from the conceptual level has to start again with the understanding of 'contact', which means nothing else than some kind of encounter of at least two different entities. All current approaches in the cultural and social sciences immediately identify this encounter as the starting point for further dynamic processes. For many archaeologists contact is defined by, and always leads to, the appearance of objects, practices, ideologies etc. from

${ }^{6}$ Pratt's understanding of 'transculturation' seems to be influenced by her background in linguistics and Bakhtin's (1981) (cf. Ackermann, 2012) notion of 'organic hybridity' - i.e. the biological understanding of hybridity - which still dominates in Linguistics (cf. Sanchez-Stockhammer, 2012).

${ }^{7}$ One could add that an important aspect of 'contact' is the contact between humans and things (e.g. Hahn, 2005;

Knappett, 2005; Miller, 2010; Stockhammer and Hahn, 2015). However, this goes beyond the scope of this article. 
different - often distant - regions. This is also the approach applied by all scholars who have studied the southern contacts of the inhabitants of the Westhallstattkreis. This is due to archaeologists' epistemological ability to identify intercultural contact, which relies on three prerequisites: first, the definition of 'archaeological cultures', whose definition is always related to spatial phenomena - in this case the 'Celts'/the Westhallstattkreis and the 'Greeks'/Mediterranean societies (Hofmann, 2015). Secondly, the perception of differences in the archaeological record in the sense that something is found and/or documented which differs from the general evidence at a certain place or area, and which, thirdly, can be linked to archaeological evidence from different places and/or archaeological 'cultures', where those objects seem to be the norm rather than the exception. Vessels produced in Athens and found in southern Germany can serve as an evident example of this.

As we have argued above, Pratt, White and most other scholars from the cultural and social sciences - especially if sympathising with postcolonial studies - commonly understand 'contact space' as the field of transculturation, hybridity, translation, misunderstandings and entanglement and, therefore, as an 'appropriation space', where the transformative dynamics of cultural encounter unfold their greatest power. These scholars emphasize the creative potential, strategies of appropriation and power asymmetries in these spaces. For them, contact spaces are marked by entangled objects and practices and, therefore, again by the existence of materialized remainders of the contact. In the past years, processes of appropriation and associated transformation of functions and/or meanings of objects have increasingly found interest of scholars engaged in the study of the Westhallstattkreis (Krauße, 2003, 2004; Kistler, 2010, Verger, 2013; Walsh, 2014). Last but not least, these processes are in the centre of interest of our ongoing collaborative research project 'BEFIM: Bedeutungen und Funktionen mediterraner Importe im früheisenzeitlichen Mitteleuropa' (www.befim.de).

To sum up: seen from a traditional point of view, archaeology identifies contact and concludes sameness; most other disciplines - and also an increasing number of archaeologists — identify contact and emphasize difference. Both kinds of approaches are linked by the fact that they base their argument on what they identify as material remnants of contact like imported objects or new technologies. However, it is also possible that an encounter has no obvious material consequences. Nevertheless, it is still an encounter. This kind of encounter, the encounter without obvious material consequences, is most difficult to understand in Prehistoric Archaeology, as the other remains absent in the record. This can always be due to conditions of preservation, as e.g. textiles, food or other organic goods hardly leave any traces unless a fortunate environment of preservation and/or cutting-edge scientific methods allow us to traces their scanty remains in the archaeological record. However, absence of material remains can also be due to human reactions after the encounter with otherness - from a lack of interest or an accidental overlooking of the other up to its intentional rejection. Depending on the degree of intentionality, the ignorance or rejection 
of the foreign has the potential to unfold most important transformative power within a society. If we take 'contact' literally, we have to include the three different dimensions of 'contact' in our analysis, i.e. acceptance, appropriation and ignorance/rejection. ${ }^{8}$ We are aware that the separation of these three aspects is purely artificial, as all three are intertwined e.g. in the moment of encounter with a foreign object or practice. Appropriating embraces accepting and rejecting at the same time. However, as rejection is so difficult to identify in the archaeological record, our differentiation should especially been considered as a reminder not to forget this important aspect.

We have to acknowledge that the default mode of human existence is not isolation, but contact and interconnectedness, accepting that the degree of such interaction was lower in prehistory due to lower population density and greater difficulty in traversing significant distances. Acceptance and appropriation of the other are rather the rule than the exception. Therefore, it is most important to ask, why certain kinds of objects, practices etc. did not find respective interest - especially if there are good arguments for the existence of cultural bounds and/or intense intercultural connectivity. Why do we find foreign architecture (like the Heuneburg mudbrick wall) only at one site, whereas the degree of connectivity and the accessibility of raw materials (in this case: clay, stones) would have allowed other sites to construct their fortification in a similar way? Why did the inhabitants of a particular settlement or within a particular space within the settlement use specific Attic vessels while those in contemporary settlements of the Westhallstattkreis did not? Simonetta Bonomi and Martin Guggisberg give examples of the particular interests of individuals north of the Alps to acquire specific Attic pottery. These choices were obviously very much guided by the particular figural motives and narratives on the respective vessels (Bonomi and Guggisberg, 2015, p. 12). The lack of material evidence for contact may mask a most vivid contact space.

What lessons can we learn from these thoughts for the archaeology of the Westhallstattkreis?

First, taking postcolonial approaches to space seriously means accepting that 'zones' do not exist as clear-cut spatial entities, but are created through social practices. Therefore, we should acknowledge the Westhallstattkreis as a dynamic feature which in its dynamic and permanent transformation can only be insufficiently illustrated when drawing its outline on a map, but it is shifting over time (cf. Brun, 1988). Moreover, as contact zones are the result of practices (of which the objects are the crucial informants) we should not only map objects to illustrate the Westhallstattkreis, but rather think of spatial dimensions of

\footnotetext{
${ }^{8}$ These three aspects were already differentiated at a very early state of anthropological discussion about intercultural contact and shaped the debate on 'acculturation' since then (cf. Redfield, Linton and Herskovits, 1936; Herskovits, 1958) - without having found much interest in Prehistoric Archaeology for a long time. Peter Burke (2000, p. 28-34) defines 'acceptance', 'rejection' and 'segregation' as the three possible reactions in context of cultural encounter. His 'acceptance' comprises our 'acceptance' as well as 'appropriation', which differentiation is especially important if one wants to understand the particularities of the archaeologists' approach.
} 
practices. The result would be the perception of the Westhallstattkreis as a less monolithic and less homogenous area.

Secondly, the general equation of the Westhallstattkreis as an archaeological category with the 'Celts' mentioned in written sources (e.g. by Herodot) has led to the assumption that this entity had already existed before the contact with the south (or at least its elite) and was subsequently transformed while it lasted. In our view, more emphasis should be laid on the process of becoming, on making the Westhallstattkreis through social practices for a particular time at a particular place. Thereby, this zone becomes a performative and dynamic social space; it becomes a contact space. Which aspects of the Westhallstattkreis are stable through time, which are dynamic, which are stablilizing over time? First studies on e.g. feasting practices have already demonstrated that there is an important dynamic development within the Westhallstattkreis that calls for further attention (e.g. Krauße, 2004). Appropriating Simone de Beauvoir's famous saying, we would state: one is not born, but rather becomes, a 'Celt'. ${ }^{9}$ Therefore, one should not focus on being, but becoming and how they made themselves by making. If the Westhallstattkreis is a dynamic contact space created within entangled practices by people who we are usually calling 'Celts', it is then the sum of all these spaces that emerge and disappear. Following our arguments, one should focus on the Westhallstattkreis in the making, rather than trying to find the 'true', 'pure' and 'compact' Westhallstattkreis.

\section{ACKNOWLEDGMENTS}

Philipp Stockhammer's contribution derives from his research within his collaborative research project "BEFIM: Bedeutungen und Funktionen mediterraner Importe im früheisenzeitlichen Mitteleuropa" which is kindly funded by the German Ministry of Science and Education (BMBF). The conceptual paragraphs on the contact zone and the third space in this article build on a previous article of the authors (STOCKHAMMER and ATHANASSOV, 2018).

9 'One is not born, but rather becomes, a woman' (De Beauvoir, 1953). 


\section{REFERENCES}

ACKERMANN, Andreas. Cultural Hybridity: Between Metaphor and Empiricism. In: STOCKHAMMER, Philipp W. (Ed.). Conceptualizing Cultural Hybridization: A Transdisciplinary Approach. Papers of the Conference, Heidelberg, 21-22 September 2009, Berlin; Heidelberg, Springer, 2012, p. 5-25.

ANTONACCIO, Carla. Networking the Middle Ground? The Greek Diaspora, Tenth to Fifth Century BC. Archaeological Review from Cambridge (Cambridge), v. 28 , n. 1, 2013, p. 241-255.

BAKHTIN, Mikhail. The Dialogic Imagination: Four Essays. Austin: University of Texas, 1981.

BONOMI, Simonetta; GUGGISBERG, Martin A. Vorwort. In: BONOMI, Simonetta; GUGGISBERG, Martin A. (Eds.). Griechische Keramiknördlich von Etrurien: mediterrane Importe im archäologischen Kontext. Wiesbaden: Reichert Verlag, 2015, p. 11-15.

BLAKE, Emma. Space, Spatiality, and Archaeology. In: MASKELL, Lynn; PREUCEL, Robert W. (Eds.). A Companion to Social Archaeology. Oxford: Blackwell, 2004, p. 230-254.

BRUN, Patrice. Les 'residences princières' comme centres territoriaux: elements de verification. In: BRUN, Patrice. Les princes celtes et la Méditeranée. Paris: Documentation Française, 1988, p. 129-143.

BURKE, Peter. Kultureller Austausch. Frankfurt: Suhrkamp, 2000.

CLIFFORD, James. Routes: Travel and Translation in the Late Twentieth Century. London: Harvard University, 1997.

CRANG, Mike; THRIFT, Nigel. Thinking Space. Cambridge, London: Routledge, 2000.

DE BEAUVOIR, Simone. The Second Sex. London: Jonathan Cape, 1953.

DELORIA, Philip J. What is the Middle Ground, Anyway? The William and Mary Quarterly (Williamsburg), v. 63, n. 1, 2006, p. 15-22.

DIETLER, Michael. Archaeologies of Colonialism: Consumption, Entanglement, and Violence in Ancient Mediterranean France. Berkeley: University of California Press, 2010.

EGGERT, Manfred K. H. Die „Fürstensitze’ der Späthallstattzeit: Bemerkungen zu einem archäologischen Konstrukt. In: LÜDTKE, Hartwig;
LÜTH, Friedrich; LAUX, Friedrich (Eds.). Archäologischer Befund und historische Deutung: Festschrift für Wolfgang Hübener. Neumünster: Karl Wachholtz Verlag, 1989, p. 53-66.

EIBACH, Joachim; OPITZ-BELAKHAL, Claudia; JUNEJA, Monica. Kultur, Kulturtransfer und Grenzüberschreitungen. Joachim Eibach und Claudia Opitz im Gespräch mit Monica Juneja. Zeitenblicke: Online Journal für die Geschichtswissenschaften, v. 11, n. 1, 2012. Available at: ‘http://crossasia-repository.ub.uniheidelberg.de/2620/s. Accessed on: 1 Aug. 2015.

FLÜCHTER, Antje; SCHÖTTLI, Jivanta. Introduction. In: FLÜCHTER, Antje; SCHÖTTLI, Jivanta (Eds.). The Dynamics of Transculturality: Concepts and Institutions in Motion. Heidelberg: Springer, 2014, p. 1-23.

FRANKENSTEIN, Susan; ROWLANDS, Michael J. The internal structure and regional context of Early Iron Age society in south-western Germany. Bulletin of the Institute of Archaeology (London), v. 15, 1978, p. 73-112. GÜNZEL, Stephan. Raum. Ein interdisziplinäres Handbuch. Stuttgart: J.B. Metzler, 2010.

HAHN, Hans Peter. Materielle Kultur: Eine Einführung. Berlin: Dietrich Reimer, 2005.

HERSKOVITS, Melville J. Acculturation: the study of culture contact. Gloucester MA: Peter Smith, 1958, $2^{\text {nd }} \mathrm{ed}$. HOFMANN, Kerstin P. (Post)Moderne Raumkonzepte und die Erforschung des Altertums. In: GEHRKE, Hans-Joachim; PONTERA, Francesco (Eds.). Geografia e storia: antico e moderno. Firenze: Leo S. Olschki, 2015, p. $25-42$.

; STOCKHAMMER; Philipp W. Materialisierte Übersetzungen in der Prähistorie. Saeculum (Köln), v. 67, n. 1, 2017, p. 45-66.

JUNEJA, Monica; FALSER, Michael. Kulturerbe Denkmalpflege: transkulturell, Eine Einleitung. In: FALSER, Michael; JUNEJA, Monica (Eds.). Kulturerbe und Denkmalpflege transkulturell: Grenzgänge zwischen Theorie und Praxis. Bielefeld: Transcript, 2013, p. 17-34.

KISTLER, Erich. Großkönigliches „symbolon' im Osten - exotisches Luxusgut im Westen, Zur Objektbiographie der achämenidischen Glasschale aus Ihringen. In: ROLLINGER, Robert (Ed.). Interkulturalität in der Alten Welt, Vorderasien, Hellas, 
Ägypten und die vielfältigen Ebenen des Kontakts. Wiesbaden: Harrassowitz, 2010, p. 63-95.

KNAPPETT, Carl. An Archaeology of Interaction: Network Perspectives on Material Culture and Society. Oxford: Oxford University Press, 2011.

Thinking through Material Culture: an Interdisciplinary Perspective. Philadelphia: University of Pennsylvania Press, 2005.

KRAUSSE, Dirk. Griechische Keramik nördlich der Alpen, Überlegungen zur Funktion der attischen Trinkschalen aus dem Kleinaspergle. In: SCHMALTZ, Bernhard; SÖLDNER, Magdalena (Eds.). Griechische Keramik im kulturellen Kontext, Akten des internationalen Vasen-Symposions in Kiel vom 24. 28.9.2001 veranstaltet durch das Archäologische Institut der Christian-Albrechts-Universität zu Kiel. Münster: Scriptorium, 2003, p. 208-210.

KRAUSSE, Dirk. 'Komos und Kottabos am Hohenasperg? Überlegungen zur Funktion mediterraner Importgüter des 6. und 5. Jhs. v. Chr. in Südwestdeutschland'. In: GUGGISBERG, Martin (Ed.). Die Hydria von Grächwil: Zur Funktion und Rezeption mediterraner Importe in Mitteleuropa. Bern, Bernisches Historisches Museum, 2004, p. 193-202.

LATOUR, Bruno. The Powers of Association. In: LAW, John (Ed.). Power, action, and belief: a new sociology of knowledge? London: Routledge \& Kegan Paul, 1986, p. 264-280.

MALKIN, Irad. Greek Ambiguities: Between 'Ancient Hellas' and 'Barbarian Epirus. In: MALKIN, Irad (Ed.). Ancient Perceptions of Greek Ethnicity. Washington DC: Center for Hellenic Studies, 2001, p. 187-212.

A Small Greek World: Networks in the Ancient Mediterranean. Oxford: Oxford University Press, 2011. THE MIDDLE GROUND: PHILOKTETES IN

ITALY. Kernos (Athens), v. 11, 1998, p. 131-141.

MARAN, Joseph. Lost in Translation: the Emergence of Mycenaean Culture as a Phenomenon of Glocalisation. In: WILKINSON, Toby; SHERRATT, Susan; BENNET, John (Eds.). Interweaving Worlds: Systemic Interactions in Eurasia, 7th to the lst Millennia BC. Papers from a Conference in Memory of Professor Andrew Sherratt. Oxford: Oxbow, 2011, p. 282-294.

MILLER, Daniel. Stuff. Cambridge: Polity, 2010.

MÜLLER-SCHEESSEL, Nils. Die Hallstattkultur und ihre räumlicheDifferenzierung. DerWest-und Osthallstattkreis aus forschungsgeschichtlich-methodologischer Sicht. Rahden/Westfalen: Verlag Marie Leidorf, 2000.

NAKOINZ, Oliver. Archäologische Kulturgeographie der ältereisenzeitlichen Zentralorte Südwestdeutschlands. Bonn: Dr. Rudolf Habelt, 2013.

Die Methode zur quantitativen Untersuchung kultureller Ähnlichkeiten im Rahmen des Projektes "Siedlungshierarchien und kulturelle Räume. In: KRAUSSE, Dirk; NAKOINZ, Oliver (Eds.). Kulturraum und Territorialität: Archäologische Theorien, Methoden und Fallbeispiele, Kolloquium des DFG-SPP 1171, Esslingen 17-18 Januar 2007. Rahden/Westfalen: Verlag Marie Leidorf, 2009, p. 87-100.

Fingerprinting Iron Age Communities in SouthWest-Germany and an Integrative Theory of Culture. In: POPA, Catalin Nicolae; STODDART, Simon (Eds.) Fingerprinting the Iron Age, approaches to identity in the European Iron Age, integrating south-eastern Europe into the debate. Oxford: Oxbow Books, 2014, p. 187-199.

ORTIZ, Fernando. Cuban Counterpoint: Tobacco and Sugar. Durham: Duke University, 1995.

PRATT, Mary Louise. Arts of the Contact Zone. Profession (New York), v. 91, 1991, p. 33-40.

Imperial Eyes: Travel Writing and Transculturation. New York: Routledge, 2008, $2^{\text {nd }}$ ed.

REDFIELD, Robert; LINTON, Ralph; HERSKOVITS, Melville J. Memorandum for the Study of Acculturation. American Anthropologist (Oxford/Arlington), v. 38, n. 1, 1936, p. 149-152.

SANCHEZ-STOCKHAMMER, Christina. Hybridization in Language. In: STOCKHAMMER, Philipp W. (Ed.). Conceptualizing Cultural Hybridization: A Transdisciplinary Approach, Papers of the Conference, Heidelberg, 21-22 September 2009. Berlin, Heidelberg: Springer, 2012, p. 133-157.

SCHORCH, Philipp. Contact Zones, Third Spaces, and the Act of Interpretation. Museum and Society (Leicester), v. 11, 2013, p. 68-81.

STOCKHAMMER, Philipp W. Conceptualizing Cultural Hybridization in Archaeology. In: STOCKHAMMER; Philipp W. (Ed.). Conceptualizing Cultural Hybridization: A Transdisciplinary Approach. Papers of the Conference, Heidelberg, 21-22 September 2009. Berlin/Heidelberg: Springer, 2012a, p. 43-58.

Performing the Practice Turn in Archaeology.

Transcultural Studies (Heidelberg), v. 1, 2012b, p. 7-42. 
; ATHANASSOV, Bogdan. Conceptualizing Contact Zones and Contact Spaces: an Archaeological Perspective. In: S. Gimatzidis/M. Pieniazek/ S. Mangaloglu-Votruba (Hrsg.), Archaeology across Frontiers and Borderlands. Fragmentation and Connectivity in the North Aegean and the Central Balkans from the Bronze Age to the Iron Age. OREA 9. Wien: Österreichische Akademie der Wissenschaften, 2018, p. 93-112.

; FORBERG, Corinna. Introduction. In: STOCKHAMMER, Philipp W.; FORBERG, Corinna (Eds.). The Transformative Power of the Copy: An Interdisciplinary and Transcultural Approach. Heidelberg: Heidelberg University Publishing, 2017, p. 1-17.

; HAHN, Hans Peter. (Eds.). Lost in Things: Fragen an die Welt des Materiellen. Münster: Waxmann, 2015.

ULF, Christoph. Eine Typologie von kulturellen Kontaktzonen („Fernverhältnisse' — Middle Grounds - dichte Kontaktzonen), oder Rethinking Cultural Contacts auf dem Prüfstand. In: ROLLINGER, Robert; SCHNEGG, Kordula; ULF, Christoph
(Eds.). Kulturkontakte in antiken Welten: vom Denkmodell zum Fallbeispiel. Proceedings des internationalen Kolloquiums aus Anlass des 60. Geburtstages von Christoph Ulf, Innsbruck, 26-30 January 2009. Leuven: Peeters, 2014, p. 469-504.

VERGER, Stéphane. Partager la viande, distribuer l'hydromel, Consommation collective et pratique du pouvoir dans la tombe de Hochdorf. In: KRAUSZ, Sophie et al (Eds.). L'Âge du Fer en Europe: Mélanges offerts a Olivier Buchsenschutz. Bordeaux: Ausonius, 2013, p. 495-504.

WALSH, Justin St. P. Consumerism in the Ancient World: Imports and Identity Construction. New York: Routledge, 2014

WHITE, Richard. Creative Misunderstandings and New Understandings. The William and Mary Quarterly (Williamsburg), v. 63, n. 1, 2006, p. 9-14.

The Middle Ground: Indians, Empires, and Republics in the Great Lake Region, 1650-1815. Cambridge: Cambridge University Press, 2011, $2^{\text {nd }}$ ed. [1991]. 